\title{
頚椎化膿性脊椎炎の経験
}

\begin{tabular}{|c|c|c|c|c|}
\hline \multicolumn{5}{|c|}{ 益田赤十字病院整形外科 } \\
\hline 倉 信 & 耕 & 爾 · 河 & 野 & 龍之助 \\
\hline 山 藤 & 良 & 史·山 & 下 & 優 嗣 \\
\hline 服 部 & 明 & 典 & & \\
\hline
\end{tabular}

\section{Pyogenic Spondylitis of the Cervical Spine}

by

\section{Koji Kuranobu, Ryuunosuke Kouno, Yoshihito Santo,} Yasutsugu Yamashita and Akinori Hattori

Department of Orthopaedic Surgery,

Masuda Red Cross Hospital, Masuda

Two cases of pyogenic spondylitis of the cervical spine are reported. One case was operated on for destructive cervical spine and another for treating the patient's neurological symptoms. Magnetic resonance imaging was useful for making an early diagnosis of this lesion and for evaluating the effects of treatment.

Key words : pyogenic spondylitis (化膿性脊椎炎), cervical spine (頝椎), magnetic resonance imaging (磁気共鳴映像法)

頚椎化膿性脊椎炎は胸椎・腰椎に比べ比較的まれで ある. 今回, 我々は澒椎化膿性脊椎炎を 2 例経験した ので文献的考察を加え報告する。

症例 164 才男性

主訴 : 頝部痛

現病歴: 平成 3 年 9 月上旬より䅡部痛, 発熱が出現 した. 近医より紹介され受診した.

\section{既往歴: 糖尿病}

現症：澒椎の可動域は著明に制限され著明な頝部痛 を認めた. 神経学的には明らかな異常は認めなかった.

血液検查所見 : 白血球 $12300 / \mu \mathrm{l}$, 赤沈值 $44 \mathrm{~mm}$ (30 分) $91 \mathrm{~mm}$ (60 分)

$\mathrm{X}$ 線所見：頝椎レントゲン像では正面像では明ら かな異常は認めなかった。側面像では䫤部痛で首をす くめているため頝椎全体像が判読できなかった.

MRI 所見：T1 強調では C4/5 椎間板は消失し C4, 5 椎体は低輝度を呈していた。T2 強調像では圧潰変 形した C4，5椎体は高輝度を呈しこれにより脊髄は 圧迫され蛇行していた（図 1).

経過：入院後抗生剂の投与と安静により顤部痛と発

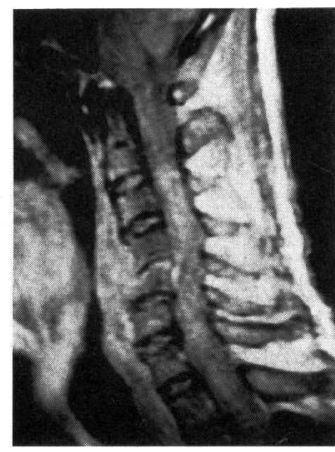

a. $\mathrm{T}_{1}$ 強調像

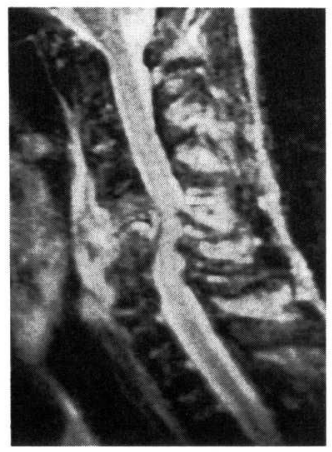

b. $\mathrm{T}_{2}$ 強調像
図 1 症例 1 . 術前 MRI 像

熱は徐々に改善した. その後レントゲン像にて C5 椎 体の圧潰と $\mathrm{C} 4 / 5$ 椎間板の不安定性, 頚椎の後弯変形 を生じたため（図 2）11月 19 日病巣择爬，骨移植術 を行った. C4/5 椎間板前方は易出血性の肉芽でおお われ椎間板は消失していた。これを可及的に掻爬し椎 体終板に出血母床を作製し腸骨より採取した移植骨を 充填した. 術後 2 カ月の時点で炎症反応は認めず頝椎 


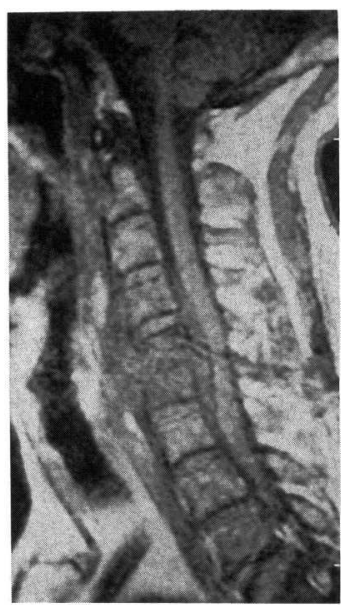

a. MRI $\mathrm{T}_{1}$ 強調像

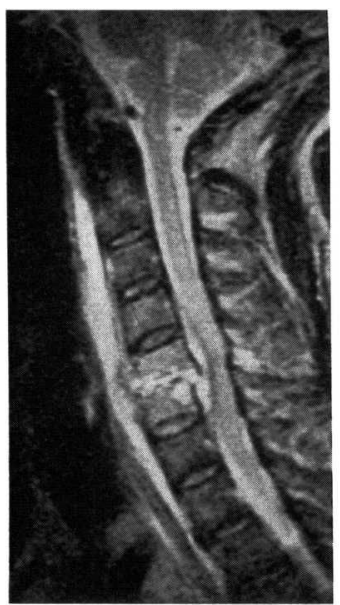

b. MRI $\mathrm{T}_{2}$ 強調像 図 3 症例 2. 術前

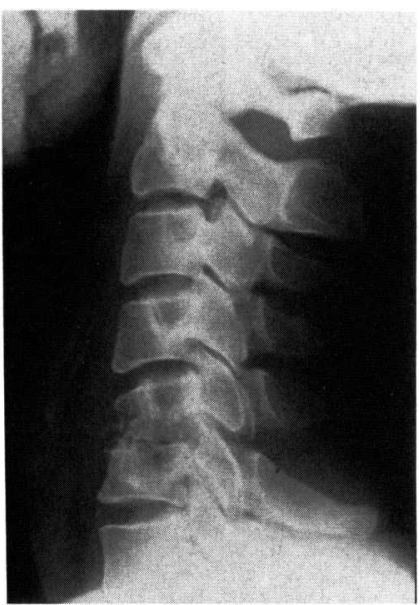

c. 術前頚椎側面 X 線像

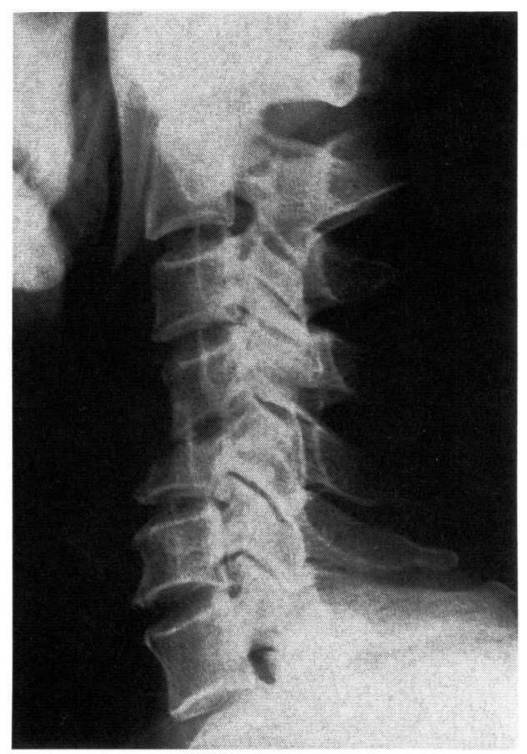

図 2 症例 1 . 術前澒椎側面 $\mathrm{X}$ 線像

のアライメントも良好で神経脱落症状も認めていない. 症例 252 才男性

現病歴: 平成 6 年 6 月中旬頃より䅡部痛と右小指の シビレ感が出現した．近位で安静加療を受けるも更に 右上肢の挙上が困難となり当院を紹介された.

既往歴：高血圧, 肝炎

血液検査所見 : 白血球 $10500 / \mu \mathrm{l}$, 赤沈 $32 \mathrm{mm（30}$

分) $67 \mathrm{~mm}$ (60 分), CRP $5.03 \mathrm{mg} / \mathrm{dl}$
現症 : 䅡椎の不撓性とともに疼痛を認めた。知覚は 右手尺側にシビレ感を認め筋力は右三角筋, 上腕二頭 筋, 上腕三頭筋の筋力低下を認めた．腱反射は右上腕 三頭筋反射と下肢腱反射は六進していた.

$\mathrm{X}$ 線所見：初診時頚椎レントゲン像で C5/6椎間板 の狭小化を認めた．脊髄造影では C6 椎体レベルで完 全停止像を示し CT ミエロでは椎体の虫食い様変化と 共に脊骾は後方へ圧排されていた。

骨シンチ像では頚椎部への高集積像を認めた.

MRI 所見 : T1 強調で C5，6 椎体の低輝度と椎体 後方に膿瘍を疑わせる像を認めこれにより春髄は後方 へ圧排されていた. T2 強調では $\mathrm{T} 1$ で低輝度部分は 高輝度となっていた (図 3).

経過 : 化膿性脊椎炎の診断のもとに頭蓋直達毫引に よる安静と抗生剤の投与を行った. 頚部痛は改善する も, 脊髄症状を認めるため手術を予定しその術前レン トゲン像では C5/6椎間板腔は消失し C 5 椎体は圧潰 し軽度後弯変形をきたしていた（図 3).MRI では椎 体後面の膿瘍像は縮小し春髄に対する圧迫は軽減して いた.

術中所見では $\mathrm{C} 5 / 6$ 椎間板は消失し椎体も破壊され ていた.この部の病理組織像では炎症細胞の中に破壊 された骨組織が存在していた. 術後軽度の後弯を認め るが不安定性も認められていない.

術後 2 カ月の MRI では脊髄に対する圧迫を認めず, 脊髄症状も改善していた（図 4 ). 


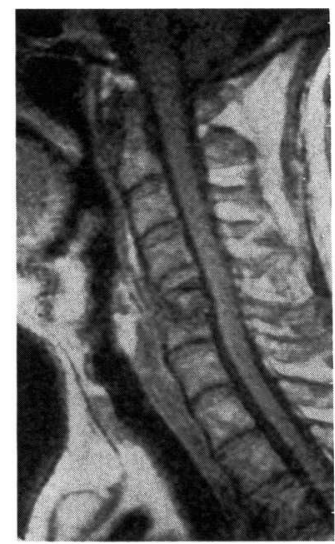

a. $\mathrm{T}_{1}$ 強調像

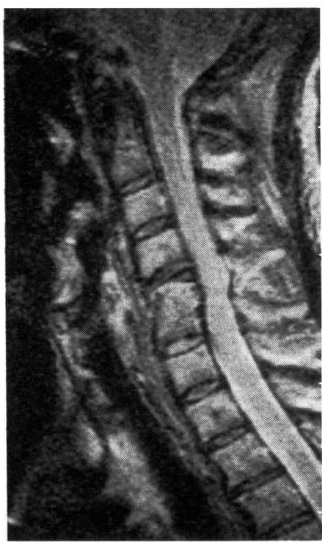

b. $\mathrm{T}_{2}$ 強調像
図 4 術後 2 力月 MRI 像

考察

化膿性脊椎炎の好発部位は腰椎で頚椎には比較的少 ない．診断には結核性脊椎炎，転移性腫瘍との鑑別が 重要であり, 従来より血液学的検査, ッ反, 単純 X 線像, CT, 核医学検査などが用いられている. 近年,
MRI の発達，普及により，諸疾患においてその有用 性がいわれている. Modic ら ${ }^{1)}$ は T1 強調像にて“椎 体と椎間板部分に一様な低信号領域”を示して，T2 強調にて逆に“高信号”を示す画像は春椎炎に特異 的であるといっている. 今回我々も同様な所見を示し た.さらに, MRIは他の検査法と比較して軟部組織 の情報が得られること, 脊髄圧迫の部位と程度が明瞭 に描出できることなどからも有用な検査である.

$$
\text { ま と め }
$$

(1)顏椎化膿性脊椎炎の 2 症例を経験した.

(2) 1 例は椎体の圧潰変形のため, もj 1 例は椎体の 圧潰変形と脊髄症状のため手術療法をおこなった。

(3)診断において MRI は X 線像より早期にその病 巣範囲を明確に把握し得た。さらに，その経時的変化 より治療効果の判定が可能であった。

\section{参 考 文 献}

1) Modic, M. T., et al.: Vertebral osteomyelitis, assessment using MR. Radiology, 157 : 157-166, 1985. 